\title{
There is no need for more than one definition of direct marketing
}

Citation for published version (APA):

Hoekstra, J. C., \& Schijns, J. M. C. (1996). There is no need for more than one definition of direct marketing. METEOR, Maastricht University School of Business and Economics. METEOR Research Memorandum No. 001 https://doi.org/10.26481/umamet.1996001

Document status and date:

Published: 01/01/1996

DOI:

10.26481/umamet.1996001

Document Version:

Publisher's PDF, also known as Version of record

\section{Please check the document version of this publication:}

- A submitted manuscript is the version of the article upon submission and before peer-review. There can be important differences between the submitted version and the official published version of record.

People interested in the research are advised to contact the author for the final version of the publication, or visit the DOI to the publisher's website.

- The final author version and the galley proof are versions of the publication after peer review.

- The final published version features the final layout of the paper including the volume, issue and page numbers.

Link to publication

\footnotetext{
General rights rights.

- You may freely distribute the URL identifying the publication in the public portal. please follow below link for the End User Agreement:

www.umlib.nl/taverne-license

Take down policy

If you believe that this document breaches copyright please contact us at:

repository@maastrichtuniversity.nl

providing details and we will investigate your claim.
}

Copyright and moral rights for the publications made accessible in the public portal are retained by the authors and/or other copyright owners and it is a condition of accessing publications that users recognise and abide by the legal requirements associated with these

- Users may download and print one copy of any publication from the public portal for the purpose of private study or research.

- You may not further distribute the material or use it for any profit-making activity or commercial gain

If the publication is distributed under the terms of Article $25 \mathrm{fa}$ of the Dutch Copyright Act, indicated by the "Taverne" license above, 


\title{
There is No Need for More than One
}

\section{Definition of Direct Marketing}

\author{
Janny C. Hoekstra \\ and \\ Jos M.C. Schijns
}

(C) 1995 University of Limburg | Maastricht

All rights reserved. No part of this publication may be reproduced or utilized in any form or by any means, electronic or mechanical, including photocopying, recording or by any information storage and retrieval system, without prior written permission from the copyright owner, or, as the case may be, the publishers, beyond the exceptions provided for in the Copyright Law. 


\title{
There is No Need for More than One Definition of Direct Marketing
}

\author{
Janny C. Hoekstra \\ and \\ Jos M.C. Schijns
}

\section{ABSTRACT}

There appear to be some problems in defining direct marketing. Bauer and Miglautsch (1992) present direct marketing as a relational marketing process. According to Schofield (1995: 36), "Such a definition excludes much marketing work which employs individual direct marketing techniques on a pragmatic and eclectic basis, alongside nondirect marketing elements, and in which the use of such techniques is normally seen as direct marketing". He suggests that two definitions may be needed: a general, inclusive definition of direct marketing, e.g. the DMAdefinition, which allows any use of any direct marketing technique to be recognized as an instance of direct marketing, and a definition of a direct marketing system, e.g. Bauer and Miglautsch's definition, covering cases where a product or service is marketed exclusively by direct marketing methods (Schofield 1995: 37). This distinction suggests that several levels of direct marketing can be distinguished.

The definition of direct marketing as proposed by Raaijmaakers et al. (1992) allows for distinguishing several levels of direct marketing without the need for more than one definition. They stress the importance of direct relationships and the specific use of marketing instruments. Based on their definition, four levels of direct marketing can be distinguished (Hoekstra 1994). Three of them concern strategic decisions and one is at the operational level (see table 1). These types cover the ever broadening field of direct marketing, including the direct marketing system as well as the use of direct marketing methods.

Table 1: $\quad$ Levels of direct marketing

\begin{tabular}{|c|c|c|}
\hline & $\begin{array}{l}\text { direct marketing for all } \\
\text { product/market } \\
\text { combinations }\end{array}$ & $\begin{array}{l}\text { direct marketing for some } \\
\text { product/market } \\
\text { combinations }\end{array}$ \\
\hline & \multicolumn{2}{|c|}{ strategic direct marketing } \\
\hline $\begin{array}{l}\text { direct communication and } \\
\text { direct distribution }\end{array}$ & $\begin{array}{l}\text { direct marketing at the } \\
\text { corporate level }\end{array}$ & $\begin{array}{l}\text { direct marketing at the } \\
\text { product(group) level }\end{array}$ \\
\hline $\begin{array}{l}\text { direct communication or } \\
\text { direct distribution }\end{array}$ & \multicolumn{2}{|c|}{ direct marketing at the instrument level } \\
\hline $\begin{array}{l}\text { ad hoc use of direct } \\
\text { marketing techniques }\end{array}$ & \multicolumn{2}{|c|}{ operational direct marketing } \\
\hline
\end{tabular}

Source: Hoekstra (1994) 


\title{
There is No Need for More than One Definition of Direct Marketing
}

\author{
Janny C. Hoekstra \\ and \\ Jos M.C. Schijns ${ }^{1}$
}

\begin{abstract}
There appear to be some problems in defining direct marketing. Bauer and Miglautsch (1992) present direct marketing as a relational marketing process. Schofield (1995: 37) suggests that two definitions may be needed: a general, inclusive definition of direct marketing, e.g. the DMA-definition, which allows any use of any direct marketing technique to be recognized as an instance of direct marketing, and a definition of a direct marketing system, e.g. Bauer and Miglautsch's definition, covering cases where a product or service is marketed exclusively by direct marketing methods. This distinction suggests that several levels of direct marketing can be distinguished.

The definition of direct marketing as proposed by Raaijmaakers et al. (1992) allows for distinguishing several levels of direct marketing without the need for more than one definition. They stress the importance of direct relationships and the specific use of marketing instruments. Based on their definition, four levels of direct marketing can be distinguished (Hoekstra 1994). Three of them concern strategic decisions and one is at the operational level. These types cover the ever broadening field of direct marketing, including the direct marketing system as well as the use of direct marketing methods.
\end{abstract}

\section{INTRODUCTION}

1

Janny C. Hoekstra is professor of marketing at the Erasmus University in Rotterdam and an associate professor of marketing at the University of Groningen, Faculty of Economics and Business Administration, P.O. Box 800, 9700 AV Groningen, The Netherlands, Telephone: +31-050-633651, Telefax: +31-050-637207, E-mail: J.C.Hoekstra@eco.rug.nl

Jos M.C. Schijns is an assistant professor of marketing at the University of Limburg, Faculty of Economics and Business Administration, Management Sciences, P.O. Box 616, 6200 MD Maastricht, The Netherlands, Telephone: +31-43-3883855, Telefax: +31-433210265, E-Mail: J.Schijns@ @mw.rulimburg.nl

The authors thank Martin Baier for his helpful comments on an earlier draft of this paper 
For several reasons it is important to know what constitutes direct marketing (Bauer and Miglautsch 1992: 8; Murrow and Hyman 1994). First, a clear definition contributes to the professional image of the (direct marketing) business area. Second, the definition delineates the area for academic purposes of research and teaching and, third, it is used for identification and communication among practioners and consultants of the area.

Bauer and Miglautsch (1992) have problems with the current (DMA) definition of direct marketing and produce a new conceptual definition, presenting direct marketing as a relational marketing process. According to Schofield (1995: 37), however, this definition is not a conceptual one, but an operational one, or the operationalization of a conceptual or theoretical definition. For that reason he suggests that direct marketing may require an unusual form of definition. He also suggests that direct marketing might need two different definitions (Schofield 1995: 33), according to the level on which direct marketing is applied in the organization. This distinction implies that direct marketing can be employed at several levels in the organization.

The definition of direct marketing as proposed by Raaijmaakers et al. (1992), and presented in this paper, allows for distinguishing several levels of direct marketing without the need for more than one definition. Defined in this way, direct marketing can be employed at several levels in the organization. Based on their definition, four levels of direct marketing can be distinguished (Hoekstra 1994). Three of them concern strategic decisions and one is at the operational level. These types cover the ever broadening field of direct marketing, including the direct marketing system as well as the use of direct marketing methods.

\section{LITERATURE REVIEW}

The official 1981 DMA definition (e.g. Baier 1985: 4; Katzenstein and Sachs 1992: 5; Roberts 
and Berger 1989: 2; Stone 1988: 3), as proposed by the DMA's statistical subcommittee (Hodgson 1989; 3), is as follows:

"Direct Marketing is an interactive system of marketing, which uses one or more advertising media to effect a measurable response and/or transaction at any location".

Several problems with this definition can be identified:

- First, advertising and sales promotions are also 'interactive'. Bauer and Miglautsch (1992: 8) note that "consumers can react in terms of brand recognition, advertisement recall, purchase intent, and purchase. All of these reactions can be measured and subsequently used by the marketer". So, defining direct marketing as an interactive system of marketing does not distinguish direct marketing from general advertising.

- Second, 'measurability' is not a specific characteristic of direct marketing. Consumer reactions to advertising or sales promotions can be measured in terms of e.g. recognition or purchase behavior, respectively. The point is that measurability distinguishes direct marketing from general marketing and advertising only in the sense that direct marketing measures response at the individual level by use of direct response advertising (Bauer and Miglautsch 1992: 9; Hoekstra and Raaijmaakers 1991).

- Third, direct marketing is presented as a particular type of selling and advertising method, while direct marketing in fact is a specific, particular, type of marketing (Bauer and Miglautsch 1992: 10; Hoekstra and Raaijmaakers 1991: 364). As Schofield (1995: 36) states, the DMA definition downgrades direct marketing "to view it as merely part of the promotional realm, whereas it is, potentially at least, a wholly distinct marketing system with its own totally separate marketing mix".

- Finally, the indication of 'at any location', in the sense that responding can take place in the home, at work or at a store, does not distinguish direct marketing from direct selling and telemarketing (Bauer and Miglautsch 1992: 9). 
Based on these problems Bauer and Miglautsch (1992: 10) propose a new definition of direct marketing:

"Direct marketing is a relational marketing process of prospecting, conversion, and maintenance that involves information feedback and control at the individual level by using direct response advertising with tracking codes".

According to Schofield (1995: 36), however, this definition excludes the use of individual direct marketing techniques 'on a pragmatic and eclectic basis', used in conjunction with nondirect marketing elements, in which the use of such techniques is normally seen as direct marketing. For that reason he suggests that direct marketing may require an unusual form of definition. He also raises the question whether direct marketing might need two different definitions (Schofield 1995: 33). The first would be a general, inclusive definition of direct marketing, e.g. the DMA-definition, which would allow any use of any direct marketing technique to be recognized as an instance of direct marketing (Schofield 1995: 37). The second definition needed would be a definition of a direct marketing system, e.g. Bauer and Miglautsch's definition, covering cases where a product or service is marketed exclusively by direct marketing methods (Schofield 1995: 37). This distinction implies that several levels of direct marketing can be distinguished. 


\section{INTRODUCTION OF A NEW DEFINITION OF DIRECT MARKETING}

The definition of direct marketing as proposed by Raaijmaakers et al. (1992) allows for distinguishing several levels of direct marketing without the need for more than one definition. Their definition runs as follows:

"Direct marketing is a form of marketing, directed at establishing, maintaining, and enhancing long term, structural, direct relationships between a supplier and his customers within a certain product market combination. In this form of marketing, the marketing instruments are employed in a specific way, of which direct communication and direct distribution are the most distinctive features."

This definition begins with the marketing concept: the customer is central to a strategy of direct marketing because it is he (or she) who decides wether a relationship truly exists.

Bauer and Miglautsch, as well as Raaijmaakers et al., consider direct marketing as being a special type of marketing, separate from and alongside, general or traditional marketing, According to Schofield (1995: 36) it is important that it is seen as such. A form of marketing implies that all marketing instruments are employed, be it in a specific way: products or services can be developed based on analysis of customer preferences, price discrimination can be applied (for instance related to the length of the relationship), and the products or services can be distributed and communicated directly to the customers. In this respect, direct communication and direct distribution are the most distinctive features of direct marketing.

Similar to the definition of Bauer and Miglautsch (1992: 13), the definition of Raaijmaakers et al. focuses on developing and maintaining an ongoing relationship between the marketer and his/her customers. And according to Murrow and Hyman (1994: 51) "... a good definition of direct marketing should imply a long-term relationship between buyers and sellers". A direct relationship, or a one-to-one relationship, refers to a situation in which two or more participants or players interact for a longer period of time, either through personal contact or 
through the media (based on Peelen, 1989). Activities performed by one player influence the other player, who reacts and thus influences the first player. Through this process of action and reaction, of playing along with each other, direct relationships develop and become more profound. In direct marketing, the process of action and reaction may consist of offering a special treatment to good customers based on analyzing buyer behavior of the target group (going along with activities of customers), and reacting to commercial messages or filing complaints against the supplier (going along with activities of the supplier). As a relationship develops, the number of interactions may rise: a customer may increase the frequency of purchase and may also buy a larger number of products. However, this need not be the case: a relationship can also be very stabel in terms of frequency and intensity of contacts. The upper limit of the number of interactions started by the supplier is largely determined by the customer's willingness to accept messages; too many contacts (e.g. mailings) may irritate the customer and deteriorate the quality and intensity of the relationship.

\section{LEVELS OF DIRECT MARKETING}

Several classifications of direct marketing applications have been proposed. Postma (1994) for instance, presents the classification as described in table 1 . The examples mentioned concern organizations that employ direct marketing on the European market. In our opinion, this presentation is only stressing the direct marketing techniques, and leaves out the more strategic implications of direct marketing.

Table 1: Direct Marketing: Matrix of Applications, some examples

\begin{tabular}{||l||l||}
\hline \multicolumn{1}{|c||}{} & \multicolumn{2}{|c|}{ ASSORTMENT } \\
\hline \hline complete & part \\
\hline \hline
\end{tabular}




\begin{tabular}{|c|c|c|c|}
\hline $\begin{array}{l}\mathrm{C} \\
\mathrm{O} \\
\mathrm{M} \\
\mathrm{M} \\
\mathrm{E} \\
\mathrm{R} \\
\mathrm{C} \\
\mathrm{I} \\
\mathrm{A} \\
\mathrm{L}\end{array}$ & entirely & $\begin{array}{l}\text { Mail order companies } \\
\text { e.g. Neckermann, Otto, Wehkamp } \\
\text { Seminar companies e.g. Euroforum } \\
\text { Game of chance companies } \\
\text { e.g. bank/girolottery } \\
\text { Financial service providers } \\
\text { e.g. Roberco, American Express }\end{array}$ & $\begin{array}{l}\text { Computersuppliers } \\
\text { e.g. DEC Direct, IBM Direct } \\
\text { Suppliers of office-equipment } \\
\text { e.g. Aspa, Ahrend Direct } \\
\text { Insurance companies and financial } \\
\text { service providers, e.g. ANWB (for } \\
\text { Internationale Reis- en } \\
\text { Kredietbrief, travel insurances), } \\
\text { Centraal Beheer (for private } \\
\text { market) }\end{array}$ \\
\hline $\begin{array}{l}\mathrm{R} \\
\mathrm{O} \\
\mathrm{U} \\
\mathrm{T} \\
\mathrm{E}\end{array}$ & partly & $\begin{array}{l}\text { Car-importers and dealers through } \\
\text { coupons, mailings in aid of leads } \\
\text { e.g. Volvo, Chrysler, BMW } \\
\text { Retail companies and airline } \\
\text { companies through cards in aid of } \\
\text { customer loyalty } \\
\text { e.g. V\&D, Bijenkorf, Formido and } \\
\text { KLM }\end{array}$ & $\begin{array}{l}\text { Manufacturers of branded articles } \\
\text { through coupons, mailings in aid of } \\
\text { heavy users } \\
\text { e.g. Procter \& Gamble and their } \\
\text { diapers } \\
\text { Banks through mailings, } \\
\text { telemarketing in aid of leads, } \\
\text { customer commitment } \\
\text { e.g. ABN AMRO, ING Bank }\end{array}$ \\
\hline
\end{tabular}

Source: Postma (1994: A1100-14)

Based on the definition described above, we propose the classification of direct marketing as presented in table 2. Four levels of direct marketing are distinguished. Three of them concern strategic decisions and one is at the operational level.

Direct marketing at corporate, product(group) and instrument level is based on strategic decisions, that influence the organization. Concepts like database management, fulfilment and the relationship focus require structural as well as cultural changes in the organization. Quality management, re-engineering and the learning organization are prerequisites for being able to create and maintain structural relationships (i.e. Webster 1993). Therefore, direct marketing at these levels will be termed strategic direct marketing. If the choice for direct marketing is made at the organizational level, then for each of the organization's product/market combinations communication and distribution is primarily done directly. In this case, direct marketing is an element of strategic market management (Raaijmaakers et al. 1992: 1383). Direct marketing at product(group) level means that for one or more, but not all, of the 
organization's product/market combinations products are primarily communicated and distributed to their respective target group(s) in a direct way.

Table 2: $\quad$ Levels of direct marketing

\begin{tabular}{|c|c|c|}
\hline & $\begin{array}{l}\text { direct marketing for all } \\
\text { product/market } \\
\text { combinations }\end{array}$ & $\begin{array}{l}\text { direct marketing for some } \\
\text { product/market } \\
\text { combinations }\end{array}$ \\
\hline & \multicolumn{2}{|c|}{ strategic direct marketing } \\
\hline $\begin{array}{l}\text { direct communication and } \\
\text { direct distribution }\end{array}$ & $\begin{array}{l}\text { direct marketing at the } \\
\text { corporate level }\end{array}$ & $\begin{array}{l}\text { direct marketing at the } \\
\text { product(group) level }\end{array}$ \\
\hline direct communication or & \multicolumn{2}{|c|}{ direct marketing at the instrument level } \\
\hline $\begin{array}{l}\text { ad hoc use of direct } \\
\text { marketing techniques }\end{array}$ & \multicolumn{2}{|c|}{ operational direct marketing } \\
\hline
\end{tabular}

Source: Hoekstra (1994: 11)

At the level of the marketing instruments, the choice for direct marketing may be one for directly communicating one or more products to one or more target group(s) and/or direct distribution for one or more product/market combinations (Raaijmaakers et al. 1992: 1383).

The fourth level of direct marketing concerns ad hoc use of direct marketing techniques, and is comparable to the use of "individual direct marketing techniques on a pragmatic and eclectic basis, alongside nondirect marketing elements" (Schofield 1995: 36). In this case, there appears to be no wish to consistently build direct relationships. Direct marketing activities at this fourth level will be termed operational direct marketing. This form of direct marketing is also applied by organizations that employ a direct distribution channel, in which customer data are only used for administrative purposes, and not for increasing the understanding of the customers. In this respect, Bauer and Miglautsch $(1992: 12,13)$ notice that "... a firm which uses direct response advertising only for lead generation would not be 
considered a direct marketer... Also, consumer goods telemarketing involved in one-shot selling would not be considered direct marketing because of the lack of conversion (a second contact) and maintenance marketing activities ... Thus, any one-shot selling program with no intent of a second contact would not be considered direct marketing". However, as Schofield (1995: 37) states, "the best way, or at least most likely way, to bring non-users to the point where they are using a direct marketing system (...) is to get them first to use some (any) direct marketing technique, to find that it works, and to be willing to acknowledge that they have been engaged in direct marketing". The fourth level of direct marketing is therefore distinguished for those users of direct marketing who can be considered to stand at the edge of direct relationships. The operational level of direct marketing takes account of this fact.

These four types fit into the definition as proposed by Raaijmaakers et al. and cover the ever broadening field of direct marketing, including the direct marketing system as well as the use of direct marketing methods. For this reason there is no need for an additional definition of direct marketing.

\section{DISCUSSION}

Bauer and Miglautsch (1992: 16) succeeded in inspiring other direct marketers and academics to critically think about and discuss what constitutes direct marketing as a distinctive substantive area of marketing, and they provided a foundation for future formal discourse on this topic. Our concern was "to define the reality of the subject or business as it really exists, not to 'define out' any direct marketing which is imperfect, or ineffective, or falls below the highest standards" (Schofield 1995: 37). This can be realized by one definition of direct 
marketing, the definition of Raaijmaakers et al. (1992):

"Direct marketing is a form of marketing, directed at establishing, maintaining, and enhancing long term, structural, direct relationships between a supplier and his customers within a certain product market combination. In this form of marketing, the marketing instruments are employed in a specific way, of which direct communication and direct distribution are the most distinctive features."

Based on this definition, four levels of direct marketing can be distinguished. Three of them concern strategic decisions and one is at the operational level. These levels cover the ever broadening field of direct marketing, including the direct marketing system as well as the use of direct marketing methods.

In practice, direct marketing is (too) often considered as being an instrument for communication, mainly aimed at getting response. The definition presented therefore stipulates the meaning of the concept: it does not describe an actual situation, but it captures the meaning by way of agreement (Koster 1991: 29). Moreover, it meets the three reasons for which it is important to know what constitutes direct marketing (the professional image of direct marketing, communication among its practitioners, and academic research and teaching).

The professional image might well be achieved by accepting that direct marketing is a distinct and separate system of marketing. It is also appropriate for defining a subject area for academic research or teaching purposes. And, by stating the level of direct marketing explicitly, it stimulates the communication among practitioners.

\section{REFERENCES}


Bauer, Connie L. and John Miglautsch (1992), "A Conceptual Definition of Direct Marketing", Journal of Direct Marketing, Volume 6, Number 2 (Spring), 7-17

Hodgson, Richard S. (1989), "Do We Need a New Definition for Direct Marketing?", Journal of Direct Marketing, Volume 3, Number 4 (Autumn), 2-5

Hoekstra, Janny C. and Mirjam C. Raaijmaakers (1991), "Betekenis en groei van direct marketing" (Meaning and Growth of Direct Marketing), Maandblad voor Accountancy en Bedrijfseconomie, Volume 65, Number 7/8 (July/August), 363-372

Hoekstra, Janny C. (1994), Direct Marketing: van respons tot relatie (Direct Marketing: Through Response to Relationships), inaugural lecture, Erasmus University Rotterdam, Wolters-Noordhoff, Groningen

Katzenstein, Herbert and William S. Sachs (1992), Direct Marketing, second edition, MacMillan, New York

Koster, J.M.D. (1991) Grondslagen van de marketingwetenschap (Fundamentals of Marketing Science), Stenfert Kroese, Leiden

Murrow, J.L. and Michael R. Hyman (1994), "Direct Marketing: Passages, Definition, and Déjà Vu", Journal of Direct Marketing, Volume 8, Number 3 (Summer), 45-56

Peelen, Ed (1989), Relaties tussen consument en aanbieder: Een basis voor herhalingsaankopen (Relationships between consumer and supplier: A basis for repeat purchases), dissertation, Haveka B.V., Alblasserdam 
Peelen, Ed, C.F.W. Ekelmans and Pieter Vijn (1989), "Direct Marketing for Establishing the Relationships Between Buyers and Sellers", Journal of Direct Marketing, Vol. 3, No. 1 (Winter), 7-14

Postma, Paul (1994), "De nieuwe marketingdynamiek" (The New Marketing Dynamics), in: Postma, Paul and Egbert Jan van Bel (eds.), Handboek Direct Marketing, Samsom, Alphen aan den Rijn, 1994, pp. A1100.1-A1100.23

Raaijmaakers, Mirjam C., Janny C. Hoekstra, Peter S.H. Leeflang and Michel Wedel (1992), "Succes of communication strategies", in: Grunert, Klaus G. and Dorthe Fuglede (eds.), Marketing for Europe Marketing for the future, Proceedings of the 21st Annual Conference of the European Marketing Academy, Aarhus, Denmark, May 26-29, 1383-1386

Roberts, Mary Lou and Paul D. Berger (1989), Direct Marketing Management, Prentice-Hall, Englewood Cliffs

Schofield, Albert (1995), "The Definition of Direct Marketing: A Rejoinder to Bauer and Miglautsch", Journal of Direct Marketing, Vol. 9, No. 2 (Spring), 32-38

Stone, Bob (1988), Succesful Direct Marketing Methods, 4th. ed., NTC Business Books, Lincolnwood, Ill.

Webster, F.E. jr. (1993), "Defining the New Marketing Concept", Marketing Management, Vol. 2, No. 4 (Fall), 37-50 